Gut, 1983, 24, 1148-1151

\title{
Effects of tripotassium dicitrato bismuthate (TDB) tablets or cimetidine in the treatment of duodenal ulcer
}

\author{
I HAMILTON, B W WORSLEY, H J O`CONNOR, AND A T R AXON
}

From the Gastroenterology Unit, The General Infirmary, Leeds

SUMMARY Forty patients with duodenal ulcer were randomly allocated to treatment with either tripotassium dicitrato bismuthate tablets or cimetidine for six weeks. Endoscopically confirmed healing of the ulcer occurred in $80 \%$ treated with tripotassium dicitrato bismuthate tablets and in $85 \%$ treated with cimetidine. Symptomatic improvement was also similar in the two groups. Treatment with cimetidine was associated with an increase in $\mathrm{pH}$ of gastric aspirate during treatment and increased numbers of bacteria were isolated from the gastric aspirate during treatment, while the $\mathrm{pH}$ and bacterial flora of gastric aspirate did not change during tripotassium dicitrato bismuthate treatment. Serum and urinary bismuth levels rose during treatment with tripotassium dicitrato bismuthate and urinary excretion remained raised two weeks after cessation of treatment. Tripotassium dicitrato bismuthate tablets appear to be as effective as cimetidine in the treatment of duodenal ulcer without the potentially undesirable effects of a reduction in gastric acid secretion.

Cimetidine has become accepted as a safe and effective form of therapy for duodenal ulcer, the majority of ulcers healing with treatment. ${ }^{1}$ There has been considerable controversy concerning the long term effects of a reduction in gastric acid secretion, particularly after showing an increase in numbers of bacteria present in the fasting stomach during treatment with cimetidine. ${ }^{2}$ It has been suggested that the production of nitrosamines within the hypochlorhydric stomach may be facilitated by the presence of bacteria and nitrite, which in turn may be produced by organisms capable of reducing dietary nitrates, and this mechanism may be implicated in the pathogenesis of gastric carcinoma. ${ }^{3}$ While the relevance of these findings is uncertain, ${ }^{45}$ the healing of duodenal ulcer without suppressing gastric acid output might have theoretical advantages.

Denol (tripotassium dicitrato bismuthate, TDB) is also an effective treatment for duodenal ulcer, but its clinical use has been limited, partly because of the inconvenience of the liquid preparation, which has an unpleasant taste and smell, and partly because of concern over the possible absorption of bismuth. The development of a tablet preparation of

Address for correspondence: Dr I Hamilton. Department of Medicine, Ninewells Hospital. Dundee DD1 9SY.

Received for publication 25 February 1983
TDB has increased the acceptability of this compound to the patient without reducing the clinical effectiveness, ${ }^{6}$ which is similar to that of cimetidine, ${ }^{7}$ and neurotoxicity, or an increase in serum bismuth levels to within the range associated with toxicity, were not seen in patients taking either solid or liquid preparations. ${ }^{6}$

We have compared the effectiveness of TDB tablets with that of cimetidine in the treatment of duodenal ulcer, in an endoscopically controlled clinical trial. We have also investigated the effects of each treatment on the $\mathrm{pH}$ of gastric juice and on the composition of the gastric bacterial flora.

\section{Methods}

Forty patients with endoscopically proven duodenal ulcer were randomly allocated, in blocks of 10 to ensure equality, to treatment with either TDB tablets (1 qds) or cimetidine $(200 \mathrm{mg}$ tds and $400 \mathrm{mg}$ nocte) for six weeks. Treatment started within two weeks of diagnosis. A detailed symptomatic questionnaire was completed and all patients were asked to keep a daily record of symptoms on a diary card provided.

All patients who had taken TDB, carbenoxolone, or $\mathrm{H}_{2}$-receptor antagonists in the three months before diagnosis, or in whom previous treatment with TDB or cimetidine had been unsuccessful, 
were excluded, as were patients who had previously undergone gastric surgery, who were pregnant, or had other serious illness - for example, renal or hepatic failure.

During the final week of treatment a clinical and endoscopic assessment was repeated, by clinicians who were not aware of the treatment group to which patients were assigned. All patients were asked to take their usual morning treatment before their second endoscopy.

Gastric juice was aspirated via the endoscope, as previously described ${ }^{2}$ at endoscopy both before and during treatment. A quantity of the aspirated juice $(0.5 \mathrm{ml})$ was immediately diluted in $4.5 \mathrm{ml}$ prereduced anaerobically sterilised glycerol broth, frozen on dry ice and subsequently subjected to detailed quantitative culture both aerobically and anaerobically, using an anaerobic cabinet (Raven, Forma Scientific Co Ltd) and previously described techniques. ${ }^{8}$ All colonial forms were identified and screened for nitrate reductase activity using the method of Cowan and Steel. ${ }^{9}$ The $\mathrm{pH}$ of the remaining aspirate was measured with a combined glass electrode (Phillips).

Blood and urine were collected from each patient before and during treatment, and blood and urine bismuth levels, renal and liver function tests, blood sugar, and serum uric acid were measured.

\section{Results}

Twenty patients were treated with cimetidine and 20 with TDB tablets. Groups were comparable with respect to age, sex, duration of current symptoms, and total length of history (Table). The degree of symptomatic relief claimed by the patient, and the duration of treatment before relief of symptoms were also similar in the two groups.

Healing of duodenal ulcers, confirmed endoscopically, occurred in $16(80 \%)$ treated with TDB tablets and $17(85 \%)$ treated with cimetidine. Ninety five per cent confidence intervals for the healing rate on TDB are 58-93\% and for cimetidine are $64-96 \% .{ }^{10}$ Using normal approximation to the binomial distribution, an approximate $95 \%$ confidence interval for the true difference between the efficacy of the two treatments in healing duodenal ulcers lies between $19 \%$ in favour of TDB and $29 \%$ in favour of cimetidine. ${ }^{10}$ There were no major side effects in either group, but staining of the mouth was noticed by 11 taking TDB and none taking cimetidine. The staining was lessened by brushing the teeth in all cases. Minor side effects of treatment were complained of by six patients taking TDB (diarrhoea, headache (two), anorexia, sore throat, and dizziness) and five taking cimetidine
Table Details of patients and response to treatment with $T D B$ tablets or cimetidine

\begin{tabular}{|c|c|c|}
\hline & TDB tablets & Cimetidine \\
\hline Patients treated & 20 & 20 \\
\hline Median age (range) & $37(21-69)$ & $44(22-62)$ \\
\hline Sex $M: F$ & $15: 5$ & $18: 2$ \\
\hline $\begin{array}{l}\text { Median length of } \\
\text { dyspeptic history }\end{array}$ & & \\
\hline (range) & $8(1-22)$ yrs & $5 \cdot 5(6-20)$ yrs \\
\hline $\begin{array}{l}\text { Mean duration of } \\
\text { present exacerbation } \\
\text { (range) }\end{array}$ & $2(1-24) \mathrm{mos}$ & $3(1-84) \mathrm{mos}$ \\
\hline Ulcers healed (\%) & $16(80)(13 \mathrm{M} ; 3 \mathrm{~F})$ & $17(85)(16 \mathrm{M} ; 1 \mathrm{~F})$ \\
\hline Symptomatic relief & & \\
\hline $\begin{array}{l}\text { Complete or only } \\
\text { occasional symptoms }\end{array}$ & 14 & 14 \\
\hline $\begin{array}{l}\text { Slight relief or } \\
\text { unchanged }\end{array}$ & 6 & 3 \\
\hline Deteriorated & - & 3 \\
\hline $\begin{array}{l}\text { Median duration of } \\
\text { treatment before } \\
\text { symptoms relieved } \\
\text { (range) }\end{array}$ & $20(1-41)$ days & $27(1-42)$ days \\
\hline
\end{tabular}

(weight loss, nausea, tiredness, dry mouth, headache).

Sufficient gastric juice to measure $\mathrm{pH}$ was aspirated at endoscopy both before and during treatment in 18 patients in either group. The mean $\mathrm{pH}$ increased from 1.8 (SD 0.6) to 2.9 (SD 1.8) during treatment with cimetidine $(\mathrm{p}<0.05$; Wilcoxon's signed rank test), the $\mathrm{pH}$ increasing in 13 of the 18 patients. Mean $\mathrm{pH}$ was $1.8(\mathrm{SD} 0.5)$ before TDB treatment, falling to 1.7 (SD 0.4 ) during treatment, the $\mathrm{pH}$ increasing in only six patients $(p>0 \cdot 1)$. This difference between groups is statistically significant $(\mathrm{p}<0.05 ;$ Fisher's test $)$ (Fig. 1).

There was also a significant increase in the total count of bacteria isolated from the gastric aspirate during cimetidine treatment $(\mathrm{p}<0.01)$, while there was no such change during treatment with TDB tablets (Fig. 2). While an increase in bacterial count tended to be associated with increased $\mathrm{pH}$, there were occasions when a more abundant bacterial flora was isolated during treatment despite little change in gastric $\mathrm{pH}$ at endoscopy. There was, however, no instance of an increase in $\mathrm{pH}$ in excess of one unit not being accompanied by an increase in numbers of bacteria isolated (Fig. 1). All organisms isolated from the stomach were probably derived from saliva and there were no 'faecal' organisms recovered; organisms tentatively identified as enterococci were found on detailed examination not to belong to Streptococcus faecalis or faecium groups. Obligate anaerobes could be isolated from the pretreatment gastric aspirate of four patients (of 


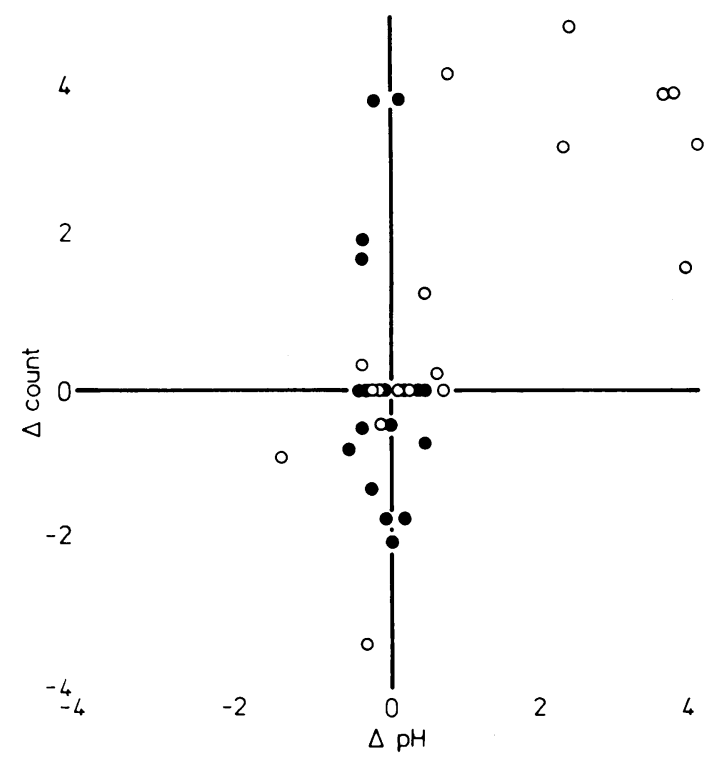

Fig. 1 Change in total bacterial count of gastric aspirate $\left(\log _{I 0}\right.$ colony forming units $\left./ m l\right)(\diamond$ count) against change in gastric $p H(\triangle p H)$ in patients treated with TDB tablets $(\bullet)$ or cimetidine $(X)$.
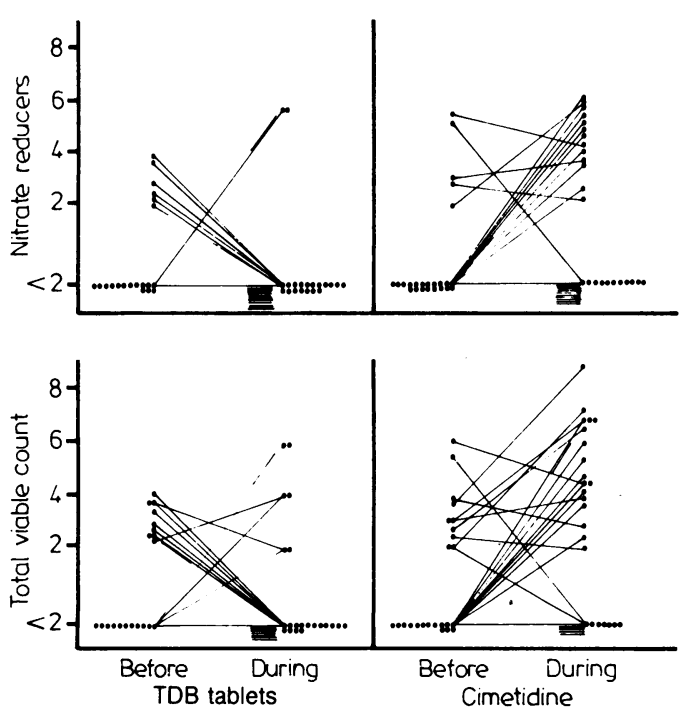

Fig. 2 Total viable bacterial count and count of nitrate reducing organisms $\left(\log _{10}\right.$ colony forming units $\left./ \mathrm{ml}\right)$ in gastric aspirate before and during treatment with $T D B$ tablets and cimetidine. whom three received TDB and one cimetidine) and from a further four patients during treatment, three of whom were taking cimetidine. Nitrate reducing bacteria were present in the stomach of nine patients before treatment, of whom six were treated with TDB tablets and three with cimetidine; during cimetidine treatment there was an increase in the count of nitrate reducing organisms in 10 patients $(p<0.05)$ while counts increased in only two taking TDB $(p>0 \cdot 1)$ (Fig. 2). The nitrate reducing organisms isolated were principally gram positive non-sporing rods or staphylococci/micrococci.

Median serum bismuth level increased during treatment with TDB from 6 (range 4-18) $\mu \mathrm{g} / \mathrm{l}$ to 13 (range 5-51) $\mu \mathrm{g} / \mathrm{l}(<0.05)$ and had returned to 7 (range 2-72) $\mu \mathrm{g} / \mathrm{l}$ two weeks after completing treatment.

Serum bismuth levels increased during treatment in 15 patients, but in only two were levels greater than $50 \mu \mathrm{g} / \mathrm{l}$ shown, in one of whom the peak level of $72 \mu \mathrm{g} / \mathrm{l}$ was present two weeks after completing treatment, the level during treatment being $30 \mu \mathrm{g} / \mathrm{l}$; the peak level in the other case, $51 \mu \mathrm{g} / \mathrm{l}$, occurred during treatment.

There was a substantial increase in urinary bismuth levels in all patients treated with TDB, the pretreatment median level of 5 (range 1-24) $\mu \mathrm{g} / 1$ rising to $240(30-710) \mu \mathrm{g} / \mathrm{l} \quad(\mathrm{p}<0.005)$. Urinary bismuth excretion remained raised at 47 (24-250) $\mu \mathrm{g} / \mathrm{l} \quad(\mathrm{p}<0.05)$ two weeks after completing treatment. Serum bismuth levels rose slightly in six patients during the course of cimetidine treatment, but median values during treatment $(4(1-30) \mu \mathrm{g} / \mathrm{l})$ were the same as those before (4 (1-9) $\mu \mathrm{g} / \mathrm{l})$ and after completing treatment $(4(1-8) \mu \mathrm{g} / \mathrm{l})$. There was no significant change in urinary bismuth excretion in this group.

There was also no change in any of the other variables measured in either treatment group.

\section{Discussion}

This comparison of TDB tablets with cimetidine does not show a statistically significant advantage of either treatment in the proportion of ulcers healing during therapy, or in the extent and rapidity of symptomatic relief. Failure to show such an advantage in a study of this nature cannot provide irrefutable evidence that the two agents are equally effective, as a comparison of two groups each of 171 patients would be necessary to give a $50 \%$ probability of detecting a 5\% difference in healing rates between them at a significance level of $0 \cdot 05 .^{19}$ Our results are compatible with cimetidine being effective in $29 \%$ more cases of duodenal ulceration than TDB, or with TDB being effective in $19 \%$ 
more cases than cimetidine, as shown by the calculation of confidence levels, and they support previous conclusions that TDB tablets and cimetidine may be equally effective in the treatment of duodenal ulcer. ${ }^{7}$

Both TDB and cimetidine have a low incidence of major side effects when used in short courses. It has been suggested that recurrence of duodenal ulcer may be less frequent after treatment with TDB than with cimetidine, ${ }^{12}$ yet any such long term advantage remains to be established by continued observation of comparable groups of patients treated with either agent. While the use of bismuth containing compounds may be associated with neurotoxicity this complication has never been reported in a patient taking TDB alone, and occurs when serum bismuth levels exceed $100 \mu \mathrm{g} / 1,{ }^{13}$ a level not encountered in this study. Persisting rise of urinary bismuth excretion after treatment suggests that there may be some tissue accumulation of bismuth, but tissue levels have not been estimated. The half life of bismuth in blood and urine after ingestion of unspecified bismuth containing compounds has been found to be similar and elimination curves of bismuth in blood and urine follow similar kinetics. ${ }^{13}$ Staining of the mouth is a reversible effect of TDB, seen more frequently with tablets than liquid, ${ }^{6}$ probably as a result of chewing the tablets.

The principal concern over the long term use of cimetidine results from its effects on the gastric acid output. The $\mathrm{pH}$ within the stomach is the major determinant of the gastric bacterial flora ${ }^{14}$ and we can confirm that a significant increase in numbers of total bacteria and nitrate reducing organisms within the stomach can occur within a few hours of taking cimetidine when fasting. ${ }^{2}$ Although the possible metabolic consequences of such changes in the gastric bacterial flora include the production of mutagenic nitroso compounds, ${ }^{3}$ the true significance of this finding remains uncertain, particularly as such marked changes in gastric $\mathrm{pH}$ and bacterial flora have not been found to result from cimetidine treatment of subject during normal activity. ${ }^{45}$ The ability to heal duodenal ulcer, however, without manipulating gastric $\mathrm{pH}$ may prove a useful therapeutic alternative.

The results of this study suggest that TDB tablets might offer such an alternative to $\mathrm{H}_{2}$-receptor antagonists in the medical management of duodenal ulcer.
We are grateful to Mr S Ogston, Department of Community Medicine, University of Dundee, for statistical advice.

\section{References}

1 Bodemar G, Walan A. Cimetidine in the treatment of active duodenal and prepyloric ulcers. Lancet 1976; 2: $161-4$.

2 Ruddell WSJ, Axon ATR, Findlay JM, Bartholomew BA, Hills MJ. Effect of cimetidine on gastric bacterial flora. Lancet $1980 ; 1:$ 672-4.

3 Ruddell WSJ, Bone ES, Hill MJ, Walters CL. Pathogenesis of gastric cancer in pernicious anaemia. Lancet 1978; 1: 521-3.

4 Muscroft TJ, Young SD, Burdon DW, Keighley MR. Cimetidine is unlikely to increase formation of intragastric $\mathrm{N}$-nitroso compounds in patients taking a normal diet. Lancet 1981; 1: 408-10.

5 Milton-Thompson GJ, Lightfoot NF, Ahmet $Z$ et al. Intragastric acidity, bacteria, nitrite and $\mathrm{N}$-nitroso compounds before, during and after cimetidine treatment. Lancet 1982; 1: 1091-5.

6 Hamilton I, Axon ATR. Controlled trial comparing Denol tablets with Denol liquid in treatment of duodenal ulcer. $\mathrm{Br}$ Med J 1981; 282: 362.

7 Van Trappen G, Rutgeerts P, Broekaert L, Jansens J. Randomised open controlled trial of colloidal bismuth subcitrate tablets and cimetidine in the treatment of duodenal ulcer. Gut 1980; 21: 329-33.

8 Hamilton I, Worsley BW, Cobden I, Cooke EM, Shoesmith JG, Axon ATR. Simultaneous culture of saliva and jejunal aspirate in the investigation of small bowel bacterial overgrowth. Gut 1982; 23: 847-53.

9 Cowan ST, Steel KJ. Manual for the identification of medical bacteria. London: Cambridge University Press, 1974: 176-7.

10 Snedecor GW, Cochran WG. Statistical methods. 6th ed. Iowa: The Iowa State University Press, 1974: 6-7.

11 Gross AJ, Clark VA. Survival distributions: reliability application in the biomedical sciences. New York: Wiley Interscience, 1975: 258.

12 Martin DF, Hollanders D, May SJ, Ravenscroft MM, Tweedle DEF, Miller JP. Difference in relapse rates of duodenal ulcer after healing with cimetidine or tripotassium dicitrato bismuthate. Lancet 1981; 1: 7-10.

13 Allain P, Chalield EJ. L'elevation des concentrations de brimuth dans les tissus de malades intoxiqués. Thérapie 1980; 35: 303-4.

14 Drasar BS. Studies on the intestinal flora. I. The bacterial flora of the gastrointestinal tract in healthy and achlorhydric subjects. Gastroenterology 1969; 56: 71-9. 